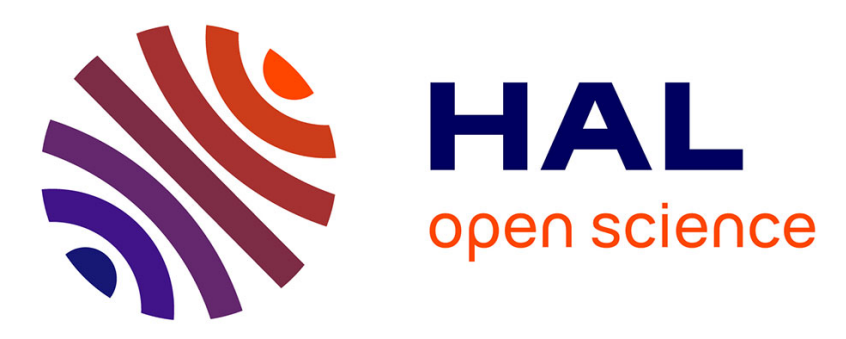

\title{
Food availability modulates the effects of maternal antibodies on growth and immunity in young feral pigeons
}

A Ismail, L Jacquin, C Haussy, S Perret, Julien Gasparini

\section{- To cite this version:}

A Ismail, L Jacquin, C Haussy, S Perret, Julien Gasparini. Food availability modulates the effects of maternal antibodies on growth and immunity in young feral pigeons. Journal of Avian Biology, 2015, 46 (5), pp.489-494. 10.1111/jav.00698 . hal-01149030

\section{HAL Id: hal-01149030 \\ https://hal.sorbonne-universite.fr/hal-01149030}

Submitted on 6 May 2015

HAL is a multi-disciplinary open access archive for the deposit and dissemination of scientific research documents, whether they are published or not. The documents may come from teaching and research institutions in France or abroad, or from public or private research centers.
L'archive ouverte pluridisciplinaire HAL, est destinée au dépôt et à la diffusion de documents scientifiques de niveau recherche, publiés ou non, émanant des établissements d'enseignement et de recherche français ou étrangers, des laboratoires publics ou privés. 
1 Food availability modulates the effects of maternal antibodies on growth

$4 \quad$ Ismail A. ${ }^{1}$, Jacquin $\mathrm{L}^{1,2}$, Haussy C. ${ }^{1}$, Perret S. ${ }^{3}$, \& Gasparini $\mathrm{J}^{1}$

5

$6{ }^{1}$ Sorbonne Universités, UPMC Univ Paris 06, UPEC, Paris 7, CNRS, INRA, IRD, Institut

9

9

10

d'Ecologie et des Sciences de l'Environnement de Paris, F-75005, Paris, France.

${ }^{2}$ Université Toulouse 3 Paul Sabatier, CNRS, ENFA ;UMR 5174 EDB (Laboratoire

Évolution \& Diversité Biologique) ; 118 route de Narbonne, F-31062 Toulouse, France

${ }^{3}$ Centre d'Ecologie Expérimentale et Prédictive CEREEP-Ecotron Ile-De-France CNRS ENS, UMS 3194, Ecole Normale Supérieure, St-Pierre-lès-Nemours, France

\section{Corresponding author}

Julien Gasparini

Institut d'Ecologie et des Sciences de l'Environnement de Paris

Université Pierre et Marie Curie, Bât. A, $7^{\text {ème }}$ étage, case 237

7 quai Saint-Bernard 75252, Paris, FRANCE

Tel: +33 (1) 44273823

Fax: +33 (1) 44273516

Email: jgaspari@snv.jussieu.fr

Running title: Food availability and maternal antibodies 
It is now widely acknowledged that mothers can transfer their own immune experience to their progeny through the allocation of specific maternal antibodies (hereafter referred as $\mathrm{Mat} A b)$ that can shape offspring phenotype and affect their fitness. However, the importance of environmental variability in modulating the effects of MatAb on offspring traits is still elusive. Using an experimental approach, we investigated how food availability interacted with MatAb to solve the trade-off between humoral immunity and growth in young feral pigeons (Columba livia). Results show that the inhibitory effect of MatAb on the humoral response of chicks was detected regardless of the food treatment. In addition, body mass growth was higher in chicks receiving lower amounts of maternal antibodies but only in chicks of the ad libitum food treatment. This contradicts previous studies and suggests that the transfer of MatAb could entail some costs for chicks and reduces their growth. Taken together these results reinforce the idea that the transfer of MatAb play a central role in shaping host life-history traits but that their adaptive value is highly dependent on the environmental context in which they take place.

Keywords: humoral response, immuno-ecology, maternal effects, transgenerational effects, trade-off. 


\section{Introduction}

The transfer of antibodies from mothers to their offspring has now been well documented in domesticated (Smith et al. 1994) and wild animals (Gasparini et al. 2001, 2002, Boulinier and Staszewski 2008, Garnier et al. 2012, 2013, Jacquin et al. 2013) and researchers have started to investigate the adaptive significance of such transfer and their consequences for hostparasite interactions (Grindstaff et al. 2003, Siegrist 2003, Gasparini et al. 2006). MatAb are transferred across the follicular epithelium into the yolk during oogenesis by an active process (Loeken \& Roth 1983; Kowalczyk 1985; Apanius 1998) and a positive correlation between antigen specific antibodies level in mother's plasma and the level in egg yolk has been reported in several studies (Apanius 1998; Blount et al. 2002; Gasparini et al. 2002; Saino et al. 2002; Morales et al. 2006). MatAb are absorbed into embryonic circulation (Kowalczyk 1985) and confer passive protection to offspring by binding and participating to the destruction of antigens encountered by the young (Wang et al. 2004; Hamal et al. 2006; Gasparini et al. 2006; Castinel et al. 2008). Since neonatal vertebrates have a limited ability to mount an immune response during the first days of their life, MatAb can provide an important protection against pathogens with beneficial effects on fitness (Heeb et al. 1998; Buechler et al. 2002; Kristan 2002; Grindstaff 2008). The persistence of MatAb in chick's circulation may be variable among individuals and species (Garnier et al. 2013), but even after they are catabolized their effects on immunity may affect offspring phenotype by influencing growth and developmental rate through potential trade-offs (Robison et al., 1988; Gustafsson et al., 1994).

A direct effect of this maternal protection is a reduction in the level of specific antigens circulating in offspring blood, which in turn should inhibit the own synthesis of antibodies by the offspring towards the same antigens (inhibitory effect). Therefore, it is possible to indirectly measure the protective role of MatAb by examining the inhibitory effect 
on the production of specific antibodies in offspring (Anderson, 1995; Carlier and Truyens 1995; Siegrist 2003; Boulinier and Staszewski 2008; Gasparini et al. 2009; Merrill and Grindstaff 2014). Using this approach, several studies confirm this adaptive effect of MatAb in different species (Gasparini et al. 2009; Staszewski et al. 2007; Staszewski and Siitari 2010; Jacquin et al. 2012; Garnier et al. 2012, 2013).

By reducing the intensity of the humoral and innate immune response of the chick, $\mathrm{MatAb}$ may also reduce the energy allocated to the immune system (Grindstaff 2008; Rutkowska et al. 2012), and therefore, may positively impact the growth of offspring (Buechler et al. 2002; Pihlaja et al. 2006; Grindstaff 2008), constituting an indirect beneficial effect of the inhibitory effect of MatAb (Boulinier and Stazsewski 2008). However, the intensity and adaptive value of such reallocation is likely to depend on the amount of resource available for the chick, so that the effect of MatAb on offspring phenotype is likely to strongly vary with environmental conditions and food availability. However, the effect of environmental heterogeneity on the effects of MatAb is still elusive.

Food availability encountered during early life has important effects on the development of the immune system (Gasparini et al. 2006) and offspring growth (Hoi-Leitner et al. 2001), and may affect the trade-offs between these two life-history traits. In particular, when food availability is low, energy is limited and trade-offs between growth and immunity might be more detectable (Soler et al. 2003; Brommer 2004; Pihlaja et al. 2006; Arriero et al. 2013). Under food limitation, we therefore expect that juveniles might reduce their investment in their humoral immune response (e.g. Bonneaud et al. 2003). Furthermore, we can also expect that the positive consequences of the inhibitory effect of MatAb on growth parameters might be more pronounced under low food availability conditions compared to high food availability conditions. 
To test these predictions we experimentally manipulated post-hatching food availability and MatAb received by chicks in feral pigeons (Columba livia) kept in captivity and examined their immune responses and growth parameters across time after antigen injections. In a previous study, we showed that limited food availability reduced the transfer of MatAb in mothers (Ismail et al. 2013). Here, we focused on the effects of these MatAb and food availability on their chicks. We investigated how food availability could modulate the inhibitory effects of MatAb on the humoral immune response of chicks and associated costs on growth. To this end, we measured the immune response and growth of chicks injected with KLH antigen (Keyhole Limpet Hemocyanin) in relation to food availability during rearing period (food availability of foster parents) and the level of MatAb transmitted.

\section{Materials and methods}

Study populations and general design

60 females and 60 males adult feral pigeons were captured in 2010 near Paris by the SACPA Company (France) under the authorization of local authorities. 10 groups of 6 females and 6 males were placed in 10 outdoor aviaries $(2.20 \mathrm{~m} \times 2.20 \mathrm{~m})$ at the CEREEP field station (CEREEP-Ecotron Ile-de-France, UMS 3194, Ecole Normale Supérieure, St-Pierre-lesNemours, France). Adults were submitted to a food and an immune treatment in a cross design. Then, eggs of similar laying date ( \pm 1 day) were swapped between nests (within or between aviaries) to obtain experimental groups of chicks differing in prenatal and postnatal female injection and food availability experienced by biological and foster parents (see Ismail et al. 2013). Using this design, we were able to investigate the interacting role of food availability and MatAb transferred on immune responses and growth parameters of chicks.

\section{Food treatment}


Young feral pigeons can fledge between 30 and 40 days of age but they are still fed by parents until the age of 50-60 days (Johnston and Janiga 1995). Food treatment of chicks was thus determined by the amount of food provided by foster parents. Food treatments of parents was initiated two weeks before the immune treatment (i.e. the 8 of March 2010) and lasted 6 months. Adult females and males $(\mathrm{N}=120)$ were randomly assigned to one of two groups: one "food-limited"'group and other "ad libitum food" group. In the" food-limited" group 60 pigeons (in five aviaries) were fed with $30 \mathrm{~g}$ of wheat per day per bird (low protein and lipid diet), corresponding to a basal diet necessary to maintain non-breeding captive pigeons (Hawkins et al. 2001). When the chicks in this group hatched, no additional food in the aviary was added during their first week of life. During their second week of life, $15 \mathrm{~g}$ per chick per day were added. From the third week onwards, $30 \mathrm{~g}$ per chick per day were added. Therefore, the food treatment of chicks was same as that of the foster parents because they were sharing the same aviary. In the "ad libitum food" group, 60 pigeons from 5 aviaries were fed $a d$ libitum with a mix of corn, wheat, and peas. All pigeons were supplemented with minerals and vitamin-enriched and water.

\section{Parental and chicks immunization treatment}

The immunization treatment of parents started two weeks after the beginning of the food treatment (i.e. the 22 of March 2010). 60 birds (three breeding pairs chosen randomly in each aviary) received a subcutaneous injection of a $100-\mu \mathrm{L}$ solution containing $0.5 \mathrm{mg} . \mathrm{mL}^{-1}$ Keyhole Limpet Hemocyanin (KLH) (antigen-injected group). The 60 remaining birds were injected with phosphate-buffered saline (PBS) (sham-injected group). A second injection was performed two weeks later to ensure that blood anti-KLH Ab levels differed between antigenand sham-injected treatment groups. Nests were monitored daily to record laying and hatching dates. We used immune treatment of females to create two groups of chicks that had or not 
received anti-KLH MatAb. We collected blood samples from 3-days-old chicks to measure their anti-KLH Ab level. This anti-KLH Ab level at 3-days-old was significantly higher in chicks from KLH-injected females (mean \pm se: $1.88 \pm 0.21$ ) than in chicks from shaminjected females $\left(0.59 \pm 0.07 ; \mathrm{F}_{1,102}=41.13, \mathrm{P}<0.0001\right)$ ensuring that we were able to create two groups of chicks differing by their levels of anti-KLH MatAb (MatAb+ group: chicks from KLH injected females and MatAb- group: chicks from sham-injected females). Note that female injection did not impact body mass $\left(\mathrm{F}_{1,102}=0.39, \mathrm{P}=0.53\right)$, tarsus size $\left(\mathrm{F}_{1,102}=0.27, \mathrm{P}\right.$ $=0.60)$ or wing size $\left(\mathrm{F}_{1,102}=0.43, \mathrm{P}=0.51\right)$ of hatchlings. We also used these blood samples to determine sex of chicks using a molecular method following Griffiths et al. (1998).

\section{Immunity and growth of chicks}

To examine the primary and secondary humoral immune response, all 21- and 35days-old chicks were injected subcutaneously with $100-\mu \mathrm{L}$ solution containing $0.5 \mathrm{mg} \cdot \mathrm{mL}^{-1}$ of KLH (the same antigen as their mother). We collected blood samples from chicks across time, i.e. $21,28,35,42,49$ and 56 days post-hatching to follow the dynamics of anti-KLH Ab production following the injections.

To examine growth during this time period, we measured body mass at each blood collection to the nearest $\mathrm{g}$, and wing size and tarsus size to the nearest $\mathrm{mm}$. We analysed the three growth variables separately because body mass, wing size and tarsus length are believed to reflect different aspects of chick quality in birds (Nilsson and Gårdmark 2001; O’Brien and Dawson 2008). Indeed, body mass depends on fat storage and is linked to fledging success, while tarsus length reflects skeletal growth patterns, and wing size depends on both skeletal and feather growth (Johnston and Janiga 1995).

Blood samples were centrifuged, and the plasma was stored at $-20^{\circ} \mathrm{C}$ for immunological assays. Anti-KLH IgY Ab levels in the plasma samples were assayed using an 
ELISA method described in Jacquin et al. (2012). Overall, 122 chicks hatched and 104 survived until 56 days. This mortality was not associated with maternal injections and food treatments (GLM for binomial distribution, Maternal injection $\mathrm{Ab}: \chi^{2}{ }_{1}=0.72, \mathrm{P}=0.40$; Food treatment of chicks: $\chi^{2}{ }_{1}=0.80, \mathrm{P}=0.37$ and their interaction: $\chi^{2}{ }_{1}=1.97, \mathrm{P}=0.16$ ). Finally, we successfully sampled 104 chicks (18 MatAb+ chicks of the restricted food treatment, 26 MatAb+ chicks of the ad libitum food treatment, 34 MatAb-chicks of the restricted food treatment and 26 MatAb-chicks of the ad libitum food treatment).

\section{Statistical analyses}

To test the effects of food treatment and MatAb on humoral immune response and growth of chicks, we performed four mixed models for repeated measures (Proc Mixed, see Littell et al. 2006) with anti-KLH Ab level, body mass, wing and tarsus size of chicks as response variables. We included the food treatment during rearing period and female injection group (reflecting the amount of antibodies transferred) as cofactors and chick age $(21,28,35,42,49$ and 56 days) as a covariate. We also added the sex of chicks as a cofactor. The foster nest and nestlings identities were included as random factors to take into account pseudoreplication issues. We compared all models possible involving second- and third-order interactions and the best-fitting models were chosen following the AICc criterion. All statistical analyses were performed using SAS (version 9.2). We used the Kenward-Roger correction to compute degrees of freedom which is recommended whenever the Proc Mixed is used for repeated measures (Littell et al. 2006). Exact $\mathrm{P}$ values are reported, and Bonferroni corrections were not applied (Moran 2003; Garcia 2004; Nakagawa 2004).

\section{Results}


Food treatment during rearing period did not affect the dynamics of anti-KLH Ab production in nestlings (Table 1), but anti-KLH MatAb had an inhibitory effect on the primary and secondary immune response of chicks (significant female injection $\mathrm{x}$ age interaction: Table 1) (Fig. 1). Indeed, statistical analyses performed at different ages show significant lower anti-KLH Ab level at 35 days (primary immune response, $P=0.009$ ) and at 42 and 49 days of age (secondary immune response, $P=0.007$ and $P=0.03$, respectively) for MatAb+ chicks as compared to MatAb- chicks. Note that at 21 days of age, MatAb+ chick had still higher maternal anti-KLH Ab level than MatAb- chicks $(P=0.03)$.

Chicks from the ad libitum food treatment had a significant higher body mass, wing and tarsus size than chicks from the restricted food treatment (Table 1). Furthermore, body mass was differently affected by the amount of maternal anti-KLH Ab transferred depending on food availability as shown by the significant interaction between female injection and food treatment. Indeed, in the ad libitum treatment group, chicks having received lower amounts of MatAb (MatAb- chicks from sham-injected females), were heavier than chicks having received higher amounts of MatAb (MatAb+ chicks from KLH injected females) (Fig. 2, Mixed Model, $\left.\mathrm{F}_{1,255}=4.40, \mathrm{P}=0.04\right)$. This difference was not found in the food restricted treatment $\left(\mathrm{F}_{1,254}=1.45, \mathrm{P}=0.23\right)$. In addition, female injection did not affect tarsus and wing size growth of chicks (Table 1).

\section{Discussion}

This study aimed at investigating the role of food variability in modulating the effects of MatAb on life-history traits of young vertebrates. The first goal was to identify the respective effect of food availability and MatAb on the humoral immune response of chicks against an injected antigen. Results show first that MatAb had an inhibitory effect on the primary and secondary humoral responses of young pigeons, as previously reported in other species (Fig. 
1; e.g. Staszewski et al. 2010). But interestingly, this inhibitory effect did not interact with food availability. Contrary to previous studies reporting an energetic cost of the humoral immune response in adults (e.g. Bonneaud et al. 2003), we did not find any negative effect of food restriction on the humoral immune response of young chicks, and chicks mounted similar immune responses against the injected antigen whatever their food treatment. One potential explanation is that when food availability is low, chicks might favor immunity at the expense of body mass and size growth (Stearns 1992). This interpretation is consistent with the negative effect of food restriction on body mass, wing and tarsus size of growing chicks (but not on immunity) found in this study. Overall, these results reinforce the idea that MatAb play a central role in neonates by modulating the immune response (Boulinier \& Staszewski 2008), and call for long term studies to elucidate the consequences of this early environmental factor on adult fitness and life-history strategies. The second aim of our study was to investigate the interacting effects of MatAb and food availability on the trade-off between immunity and growth. We expected a higher growth of chicks having received a higher amount of MatAb, because MatAb are supposed to allow chicks to save energy for growth by reducing the cost of mounting a humoral immune response. Contrary to our expectations, we found that body mass growth was higher in chicks receiving lower amounts of MatAb in the ad libitum food treatment (Fig. 2). This contrasts with previous studies that either failed to detect an effect of MatAb on growth (Grindstaff et al. 2006, Staszewski et al. 2007) or found positive effects of MatAb on growth parameters (Heeb et al. 1998, Grindstaff 2008). Our results rather suggest that receiving MatAb entails 239 some costs for chicks in terms of growth and does not enable them to save energy from a costly immune response. This is consistent with a previous study on pigeons in which we found, on a smaller sample size, that postnatal non-specific MatAb could impair growth 
(Jacquin et al. 2012). This study provides the first experimental evidence of a cost associated with MatAb.

As we performed a cross-fostering experiment and swapped eggs between nests, this negative effect of MatAb on growth cannot be explained by differences in postnatal parental care (for instance, differences in feeding rates). Although further studies will be necessary to decipher the underlying mechanisms, this negative effect of MatAb on body mass might be explained by differences in nutrients or hormones packed into the eggs. Indeed, in 2008, Boulinier and Staszewski suggested that MatAb transfer might represent a significant energy drain for females since high amounts of antibodies are diverted from blood circulation into the eggs (10 to $20 \%)$. This could impact the ability of mothers to transfer other substances, such as nutrients or hormones, into the eggs, which could potentially impact offspring growth (Gasparini et al. 2007). For instance, it is possible that injected mothers could transfer higher amounts of MatAb at the expense of other proteins and molecules in their eggs (for instance lysozymes, vitamins, corticosterone, carotenoids). Further experimental works will help investigating potential trade-offs between MatAb and other active substances in eggs and elucidate the underlying mechanisms of this negative effect of MatAb on offspring growth.

In conclusion, this study reinforces the idea that variations in resource availability can strongly impact the effects of MatAb on the ontogeny of life-history traits. Since wild animal populations will likely be submitted to increased resource fluctuations due to global changes, we advocate to explicitly take into account such interacting effects of resource availability and MatAb since they could determine the outcome of host-parasite interactions across generations and affect pathogen epidemiology in wild populations

\section{Acknowledgments}


266 We are very grateful to Julie Ducorbier, Loic Chauvin, Anne-Caroline Prévot-Julliard, Gérard 267 Leboucher, Hélène Corbel, Philippe Lenouvel, and the CEREEP station for the help they 268 provided at different stages of the study. This study was carried out in accordance with the 269 recommendations of the European Convention for the Protection of Vertebrate Animals used 270 for Experimental and Other Scientific Purposes (revised Appendix A). All experiments and 271 captures were approved by local authorities and the "Direction Départementale des Services 272 Vétérinaires de Seine-et-Marne” (permit No. 77-05). This work was financed by grants from 273 the région Ile-de-France (Sustainable Development Network R2DS, No. 2008-07). L. Jacquin 274 was supported by a Ph.D. fellowship from the French Ministry of Research and a postdoctoral 275 Fyssen fellowship. A. Ismail was supported by a scholarship from Damascus University in 276 Syria. 


\section{References}

Anderson, R. W. 1995. On the maternal transmission of immunity: a 'molecular attention' hypothesis. Bio. Systems. - 34: 87-105.

Apanius, V. 1998. Ontogeny of immune function. - In: Starck, J.M. and Ricklefs, R.E. eds, Avian Growth and Development - Evolution Within the Altricial-Precocial Spectrum. Oxford University Press, Oxford, pp. 203-222.

Arriero, E., Majewska, A. and Martin, T. E. 2013. Ontogeny of constitutive immunity: maternal vs. endogenous influences. - Funct. Ecol. 27: 427478.

Blount, J. D., Surai, P. F., Nager, R. G., Houston, D. C., Møller, A. P., Trewby, M. L. and Kennedy, M. W. 2002. Carotenoids and egg quality in the lesser black-backed gull larus fuscus: A supplemental feeding study of maternal effects. - Proc. R. Soc. Lond. B. 269: 29-36.

Bonneaud, C., Mazuc, J., Gonzalez, G., Haussy, C., Chastel, O., Faivre, B. and Sorci, G. 2003. Assessing the cost of mounting an immune response. - Am. Nat. 161: 367-379.

Boulinier, T. and Staszewski, V. 2008. Maternal transfer of antibodies: raising immunoecology issues. -Trends. Ecol. Evol. 23: 282-288.

Brommer, J. E. 2004. Immunocompetence and its costs during development: an experimental study in blue tit nestlings. - Proc. R. Soc. Lond. B. 271: S110-S113.

Buechler, K., Fitze, P. S., Gottstein, B., Jacot, A. and Richner, H. 2002. Parasite-induced maternal response in a natural bird population. - J. Anim. Ecol. 71: 247-252.

Carlier, Y. and Truyens, C. 1995. Influence of maternal infection on offspring resistance towards parasites. - Parasitol. Today. 11: 94-99.

Castinel, A., Kittelberger, R., Pomroy, W. E., Duignan, P. J., Chilvers, B. L. and Wilkinson, I. S. 2008. Humoral immune response to Klebsiella spp. in New Zealand sea lion 
(phocarctos hookeri) and the passive transfer of immunity to pups. - J. Wildl. Dis. 44: 8-15.

Garcia L.V. 2004. Escaping the Bonferroni iron claw in ecological studies. - Oikos 105: 657663.

Garnier, R., Ramos, R., Staszewski, V., Militão, T., Lobato, E., Gonzalez-Solıs, J. and Bouliner, T. 2012. Maternal antibody persistence: a neglected life history trait with implications from albatross conservation to comparative immunology. - Proc. R. Soc. B. 279: 2033-2041.

Garnier, R., Boulinier, T. and Gandon, S. 2013. Evolution of the temporal persistence of immune protection. - Biol. Lett. 9: 20130017.

Gasparini, J., McCoy, K. D., Haussy, C., Tveraa, T. and Boulinier, T. 2001. Induced maternal response to the Lyme disease spirochete Borrelia burgdorferi sensu lato in a colonial seabird, the kittiwake Rissa tridactyla. - Proc. R. Soc. B. 268: 647-650.

Gasparini, J., McCoy, K. D., Tveraa, T. and Boulinier, T. 2002. Related concentrations of specific immunoglobulins against the Lyme disease agent (Borrelia burgdorferi sensu lato) in eggs, young and adults of the kittiwake (Rissa tridactyla). - Ecol. Lett. 5: 519524.

Gasparini, J., McKoy, K. D., Staszewski, V., Haussy, C. and Boulinier, T. 2006. Dynamics of anti-Borrelia antibodies in Black legged Kittiwake (Rissa tridactyla) chicks suggest maternal educational effect. - Can. J. Zool. 84: 623-627.

Gasparini, J., Boulinier, T., Gill, V. A., Gil, D., Hatch, S. A. and Roulin, A. 2007. Food availability affects the maternal transfer of androgens and antibodies into eggs of a colonial seabird. - J. Evol. Biol. 20: 874-880.

Gasparini, J., Piault, R., Bize, P. and Roulin, A. 2009. Pre-hatching maternal effects inhibit nestling humoral immune response in the tawny owl. - J. Avian. Biol. 40: 271-278. 
Griffiths, R., Double, M. C., Orr, K. and Dawson, R. J. G. 1998. A DNA test to sex most birds. - Mol. Ecol. 7: 1071-1075.

Grindstaff, J. L., Brodie, E. D. III. and Ketterson, E. D. 2003. Immune function across generations: integrating mechanism and evolutionary process in maternal antibody transmission. - Proc. R. Soc. B. 270: 2309-2320.

Grindstaff, J. L., Hasselquist, D., Nilsson, J-A., Sandell, M., Smith, H. G. and Stjernman, M. 2006. Transgenerational priming of immunity: maternal exposure to a bacterial antigen enhances offspring humoral immunity. - Proc. R. Soc. B. 273: 2551-2557.

Grindstaff, J. L. 2008. Maternal antibodies reduce costs of an immune response during development. - J. Exp. Biol. 211: 654-660.

Gustafsson, E., Mattsson, A., Holmdahl, R. and Mattsson, R. 1994. Pregnancy in B-cell deficient mice: postpartum transfer of immunoglobulins prevents neonatal runting and death. - Biol. Reprod. 51: 1173-1180.

Hamal, K. R., Burgess, S. C., Pevzner, I. Y. and Erf, G. F. 2006. Maternal antibody transfer from dams to their egg yolks, egg whites, and chicks in meat lines of chickens. - Poult. Sci. 85: 1364-1372.

Hawkins, P., Morton, D. B, Cameron, D, Cuthill, I, Francis, R. et al. 2001. Laboratory birds, refinements in husbandry and procedures. - Lab Anim 35:109-115.

Heeb, P., Werner, I., lliker, M. K. and Richner, H. 1998. Benefits of induced host response against an ectoparasite. - Proc. R. Soc. B. 265: 51-56.

Hoi-Leitner, M., Romero-Pujante, M., Hoi, H. and Pavlova. A. 2001. Food availability and immune capacity in serin (Serinus serinus) nestlings. - Behav. Ecol. Sociobiolo. 49: 333-339. 
Ismail A., Jacquin L., Haussy C., Legoupi J., Perret S. and Gasparini, J. 2013. Food availability and maternal immunization affect transfer and persistence of maternal antibodies in nestling pigeons. - PLOS. One. 8: e79942.

Jacquin, L., Blottière, L., Haussy, C., Perret, S. and Gasparini, J. 2012. Prenatal and postnatal parental effects on immunity and growth in 'lactating' pigeons. - Funct. Ecol. 26: 866-875.

Jacquin, L., Haussy, C., Bertin, C., Laroucau, K. and Gasparini, J. 2013. Darker females transmit more specific antibodies to their eggs than paler ones in feral pigeons. - Biol. J. Linn. Soc. 108: 647-657.

Johnston R. F. and Janiga M. 1995. Feral pigeons - Oxford University Press, Oxford.

Kowalczyk, K., Daiss, J., Helpern, I. and Roth, T. F. 1985. Quantitation of maternal-fetal IgG transport in the chicken. - Immunology. 54: 755-762.

Kristan, D. M. 2002. Maternal and direct effects of the intestinal nematode Heligmosomoides polygyrus on offspring growth and susceptibility to infection. - J. Exp. Biol. 205: 3967-3977.

Littell, R. C., Milliken, G. A., Stroup, W. W. and Wolfinger, R. D. 2006. SAS System for Mixed Models (second edition). - Cary, NC, SAS Institute Inc.

Loeken, M. R. and Roth, T. F. 1983. Analysis of maternal IgG subpopulations which are transported into the chicken oocyte. - Immunology, 49: 21-28.

Merrill, L. and Grindstaff, J. L. 2014. Maternal antibody transfer can lead to suppression of humoral immunity in developing Zebra Finches (Taeniopygia guttata). - Physiol. biochem. zool. 87: 740-751.

Moran, M. D. 2003. Arguments for rejecting the sequential Bonferroni in ecological studies. Oikos 100: 403-405. 
Morales, J., Sanz, J. J, Moreno, J. 2006. Egg colour reflects the amount of yolk maternal antibodies and fledging success in a songbird. - Biol. Lett. 22: 334-336.

Nakagawa, S. 2004. A farewell to Bonferroni: the problems of low statistical power and publication bias. - Behav. Ecol. 15: 1044-1045.

Nilsson, J. A. and Gårdmark, A. 2001. Sibling competition affects individual growth strategies in marsh tit, Parus palustris, nestlings. - Anim. Behav. 61: 357-365.

O'Brien, E. L. and Dawson, R. D. 2008. Parasite-mediated growth patterns and nutritional constraints in a cavity-nesting bird. - J. Anim. Ecol. 77: 127-134.

Pihlaja, M., Siitari, H. and Alatalo, R. V. 2006. Maternal antibodies in a wild altricial bird: effects on offspring immunity, growth and survival. - J. Anim. Ecol. 75: 1154-1164.

Robison, J. D., Stott, G. H. and DeNise, S. K. 1988. Effects of passive immunity on growth and survival in the dairy heifer. - J. Dairy Sci. 71: 1283-1287.

Rutkowska, J., Martyka, R., Arct, A. and Cichoń, M. 2012. Offspring survival is negatively related to maternal response to sheep red blood cells in zebra finches. - Oecologia 168: 355-359.

Saino, N., Dall'ara, P., Martinelli, R. and Møller, A. P. 2002. Early maternal effects and antibacterial immune factors in the eggs, nestlings and adultes of the barn swallow. - J. Evol. Biol. 15: 735-743.

Siegrist, C-A. 2003. Mechanisms by which maternal antibodies influence infant vaccine responses: review of hypotheses and definition of main determinants. - Vaccine 21: 3406-3412.

Smith, N. C., Wallach, M., Petracca, M., Braun, R. and Eckert, J. 1994. Maternal transfer of antibodies induced by infection with Eimeria maxima partially protects chickens against challenge with Eimeriatenella. - Parasitology 109: 551-558. 
397 Soler, J. J., de Neve, L., Perez-Contreras, T., Soler, M. and Sorci, G. 2003. Trade-off between immunocompetence and growth in magpies: an experimental study. - Proc. R. Soc. Lond. B. 270: 241-248.

400 Staszewski, V., Gasparini, J., McKoy, K. D., Tveraa, T. and Boulinier, T. 2007. Evidence

401

402

403

404

405

406

407

408 of an interannual effect of maternal immunization on the immune response of juveniles in a long lived colonial bird. - J. Anim. Ecol. 76: 1215-1223.

Staszewski, V. and Siitari, H. 2010. Antibody injection in the egg yolk: maternal antibodies affect humoral immune response of the offspring. - Funct. Ecol. 24: 1333-1341.

Stearns, R. C. 1992. The evolution of life histories. - Oxford University Press, Oxford.

Wang, Y. W., Sunwoo, H., Cherian ,G., Sim, .J. S. 2004. Maternal dietary ratio of linoleic acid to alpha-linolenic acid affects the passive immunity of hatching chicks. - Poult. Sci. 83: 2039-2043. 
409 Table 1. Output of the best-fit generalized mixed models explaining variations in anti-KLH

$410 \mathrm{Ab}$ levels, body mass, wing and tarsus size in chicks as they age in interaction with the food 411 treatment during rearing period and the female injection. Sex was added as a cofactor. All 412 interactions removed from the final model were non-significant. 


\begin{tabular}{|c|c|c|c|c|c|c|c|c|c|c|c|c|}
\hline \multirow[b]{2}{*}{ Effects } & \multicolumn{3}{|c|}{ Anti-KLH Ab level } & \multicolumn{3}{|c|}{ Body mass } & \multicolumn{3}{|c|}{ Wing size } & \multicolumn{3}{|c|}{ Tarsus Size } \\
\hline & $\mathrm{DF}$ & $\mathrm{F}$ & $\mathrm{P}$ & $\mathrm{DF}$ & $\mathrm{F}$ & $\mathrm{P}$ & $\mathrm{DF}$ & $\mathrm{F}$ & $\mathrm{P}$ & $\mathrm{DF}$ & $\mathrm{F}$ & $\mathrm{P}$ \\
\hline Age & 5,502 & 97.72 & $<0.001$ & 5,499 & 135.9 & $<0.001$ & 5,500 & 2048.42 & $<0.001$ & 5,500 & 28.29 & $<0.001$ \\
\hline Food treatment & $1,40.9$ & 1.91 & 0.17 & $1,34.6$ & 16.4 & $<0.001$ & $1,43.6$ & 3.48 & 0.07 & $1,36.4$ & 11.59 & 0.002 \\
\hline Female injection & $1,92.6$ & 5.15 & $\mathbf{0 . 0 3}$ & $1,86.5$ & 0.09 & 0.77 & 1,98 & 0.01 & 0.93 & $1,89.8$ & 0.04 & 0.83 \\
\hline Sex & $1,93.7$ & 2.01 & 0.16 & $1,94.1$ & 11.57 & 0.001 & $1,86.5$ & 9.66 & 0.003 & $1,92.8$ & 24.58 & $<0.001$ \\
\hline Age $x$ Female injection & 5,502 & 3.77 & 0.002 & 5,499 & 0.52 & 0.76 & 5,500 & 0.58 & 0.72 & - & - & - \\
\hline $\begin{array}{l}\text { Female injection } \mathrm{x} \\
\text { Food treatment }\end{array}$ & - & - & - & $1,85.2$ & 4.32 & 0.04 & $1,97.9$ & 0.54 & 0.46 & $1,88.8$ & 0.91 & 0.34 \\
\hline Age $x$ Food treatment & - & - & - & 5,499 & 0.96 & 0.44 & 5,500 & 1.00 & 0.42 & - & - & - \\
\hline $\begin{array}{l}\text { Female injection } \mathrm{x} \\
\text { Food treatment } \mathrm{x} \text { age }\end{array}$ & - & - & - & 5,499 & 0.83 & 0.53 & 5,500 & 0.47 & 0.80 & - & - & - \\
\hline
\end{tabular}


Fig. 1. Humoral immune response of chicks over time, measured by anti-KLH Ab level in relation to maternal level of anti-KLH Ab. Chicks were split into two categories on whether they received (MatAb+: KLH injected mother) or not (MatAb-: sham-injected mother) antiKLH from their mothers. MatAb+ chicks are represented by black squares and MatAb- chicks are represented by white dots. The arrows signal the timing of KLH injections.

Fig. 2. Chicks body mass as they age in relation to maternal injection (MatAb+vs. MatAb-) and the food treatment. MatAb+ Chicks of the restricted food treatment are represented by white squares, MatAb+ chicks of the ad libitum food treatment are represented by black squares, MatAb- chicks of the restricted food treatment are represented by white dots and MatAb- chicks of the ad libitum food treatment are represented by black dots. 
Fig. 1.

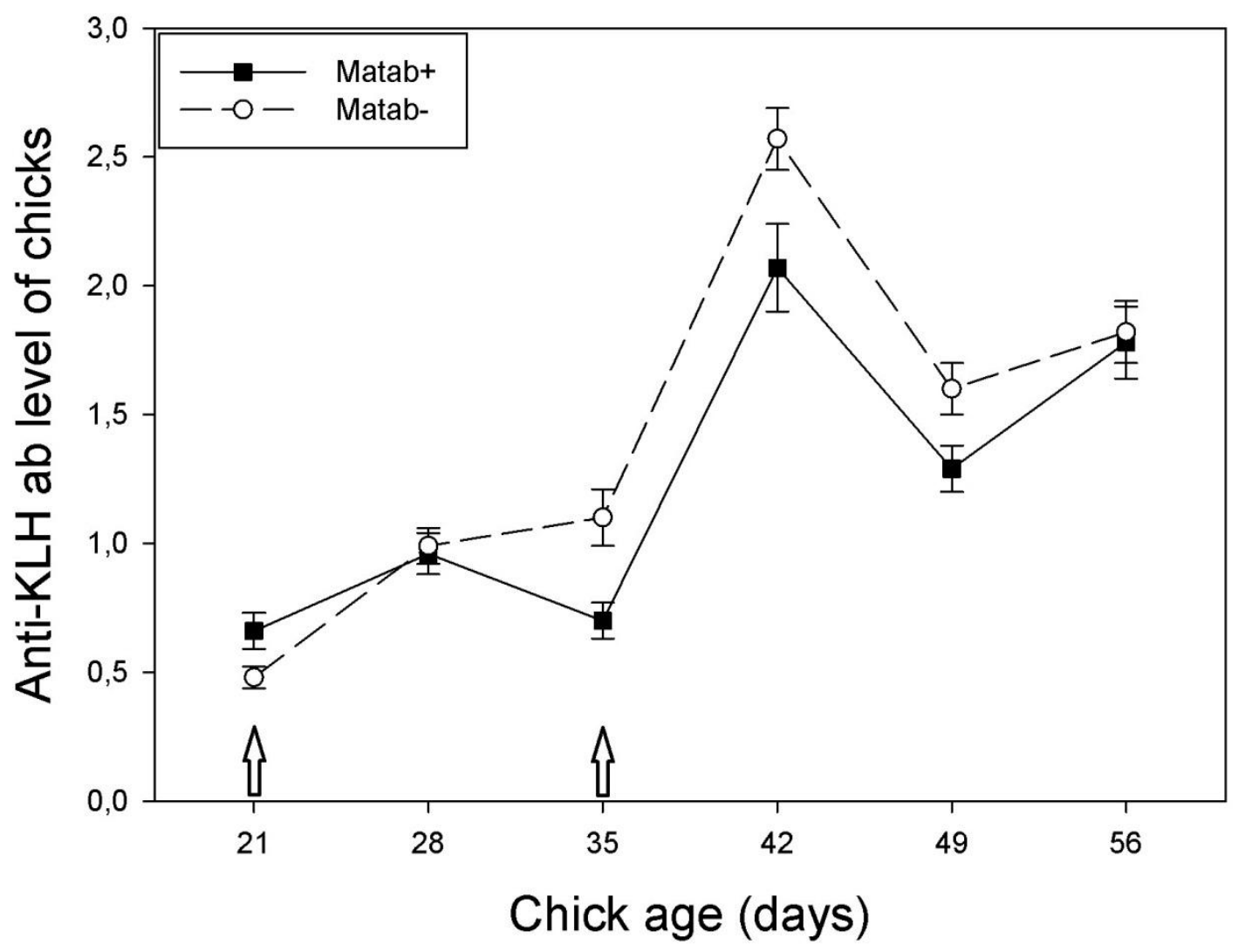


Fig. 2

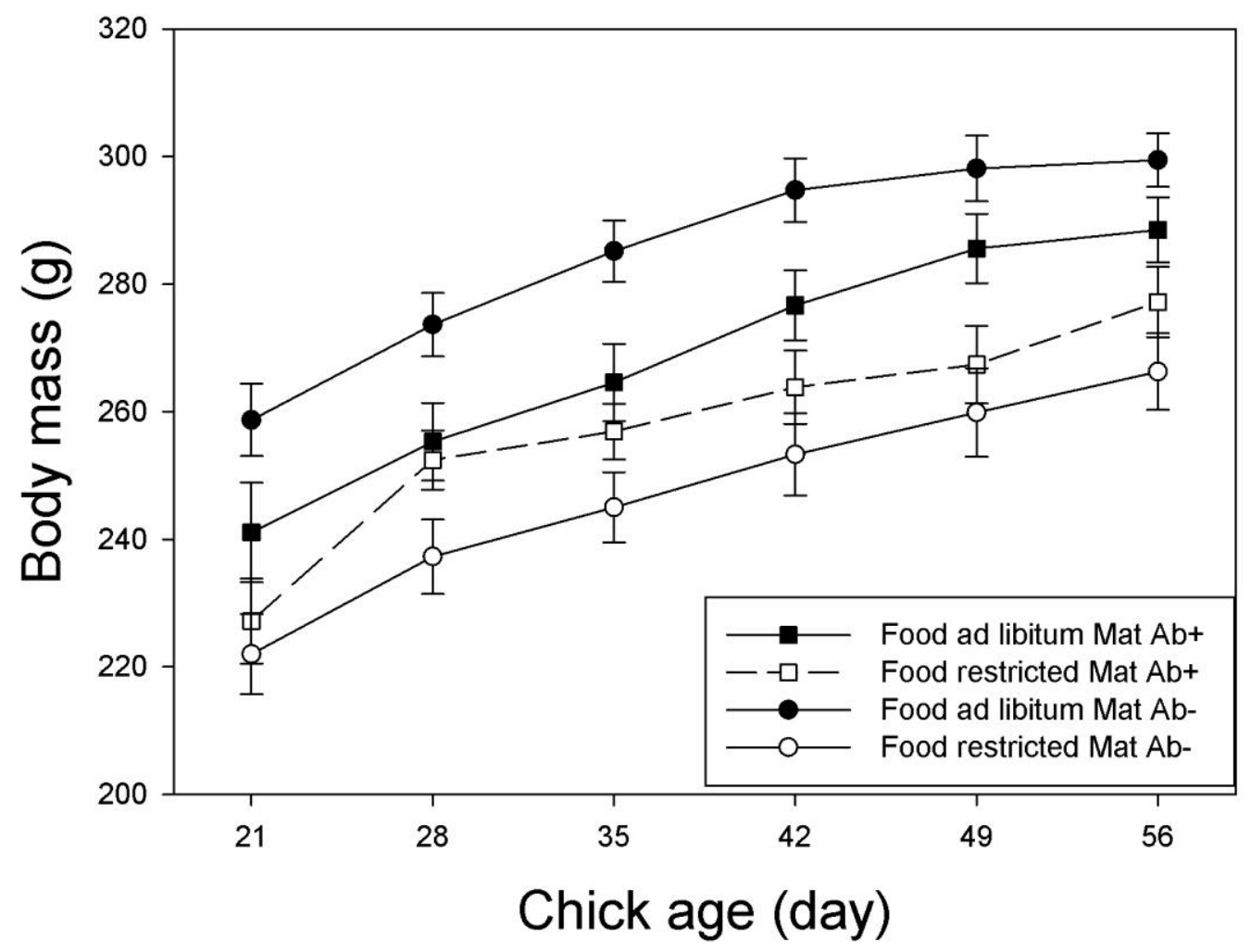

